\title{
Physico-Chemical Analysis of Ground Water in the Selected Area of Visakhapatnam, AP, India
}

\author{
E. Madhusudan Yaduvams ${ }^{1}$, S.V. Ranga Rao ${ }^{2}$, CH. Venkata Ramana ${ }^{1 *}$ and \\ T. Byragi Reddy ${ }^{1}$ \\ ${ }^{1}$ SMBTAV \& SN Degree College, Veeravasaram, AP, India \\ ${ }^{2}$ Department of Environmental Sciences, Andhra University, Visakhapatnam, AP, India \\ *Corresponding author
}

\section{A B S T R A C T}

\section{Keywords}

Ground water,

Physico-chemical analysis and over exploration.

Article Info

Accepted:

10 October 2017

Available Online:

10 December 2017
Ground water is important source for industrial, agricultural and domestic purpose. Recent decades, due to over exploration of ground water is drastically decreased. Our present study, carried out of physico-chemical analysis of ground water, Visakhapatnam, AP, India. Major parameters like $\mathrm{pH}$, Electrical Conductivity, Total Dissolved Solids (TDS), Chlorides, Sulphate, Total Hardness, Total Alkalinity, Nitrates and Dissolved Oxygen (DO) were analyzed. Results showed that the most of the parameters were exceeded the recommended ground water quality levels of Bureau of Indian Standards (BIS). Results indicated ground water is slightly polluted and recommended to treatment of ground water it's before use.

\section{Introduction}

Ground Water quality plays an important role in groundwater protection and quality conservation. Hence, it is very important to assess the groundwater quality not only for its present use but also from the viewpoint of a potential source of water for future consumption (Kori et al., 2006). It is well known that occurrence of ground water and its availability for various uses is controlled by the nature of rock formation in which it occurs as well as geological structures, geomorphologic and hydrological setting and hydrometreological conditions. This resource is generally developed through ponds, lakes, wells and tube wells depending up on the need for which it is being used and its availability in the area (Raju, 1983).

An uncontrolled use of bore-well technology has lead to the extraction of ground water at such a high rate that often recharge is not sufficient. Water intended for human consumption should be "safe and wholesome" i.e. free from pathogenic agent and harmful chemicals, pleasant to taste and useable for domestic purpose (Parashar et al., 2006). The study area selected was all over urban area of Visakhapatnam for ground water quality testing. The city is dividing into five different zones, and six samples are collected from 
each zone. The physico-chemical parameters like $\mathrm{pH}, \mathrm{EC}$, Total hardness, Total alkalinity, Chloride, Sulphate, Sodium, Potassium, Mg and Nitrate were studied to analyze the potable ground water quality of the city of lakes. Water is the principal need of life on earth, the requirement of water in all lives, from microorganism to man is a serious problem today because all water resource have been reached to a point of crises due to unplanned urbanization and industrialization (Singh et al., 2002). Water pollution is the state of deviation from pure condition, whereby its normal functioning and properties are affected. Aggravated environment problems often reflect the misuse or misunderstanding of technology (Petak, 1980).

\section{Materials and Methods}

The study area selected was total urban area of the city of Destiny, Visakhapatnam, Andhra Pradesh, India. The study area is located between latitude- $17^{\circ} 30^{\prime} 15^{\prime \prime}$ to $18^{\circ}$ $11^{\prime} 15^{\prime \prime}$ North and longitude- $82^{\circ} 57^{\prime} 37^{\prime \prime}$ to $83^{\circ} 28^{\prime} 12^{\prime \prime}$ East. Visakhapatnam has been notified as one of the most polluted industrial cluster by central pollution control board of India. The study area experiences a semi-arid climate, with temperature in the range of 14 $38^{\circ} \mathrm{C}$. The annual average rainfall is 1080 $\mathrm{mm}$. The sub-surface geology indicates that the average weathered rock portion extends up to $16 \mathrm{~m}$ and the fractured rock zone up to $30 \mathrm{~m}$ depth from the ground surface. The red sediments vary in depth from 1 to $3 \mathrm{~m}$, with an average of about $2 \mathrm{~m}$, from surface level, depending upon the topography. Water samples were drawn from bore-wells and hand pumps during Post-monsoon period of the year 2013. The water samples were collected in plastic container as possible to avoid unpredictable changes in physicochemical characteristics. The testing of samples was done according to the procedure prescribed by APHA (2005). Present study comprises of interpretation and analysis of water samples collected from thirty different stations at all over city. In our study, first we mark the sampling stations in five different zones of the city, then stations were established and water samples were collected. The samples were analyzed for different chemical, physical parameters and the results were carefully studied and analyzed.

\section{Results and Discussion}

Ground-water has been considered a safe source of potable water since the ages and till date a lot of people depend on it for drinking. But the quality of ground water is deteriorating and it is of paramount importance to assess the quality regarding various parameters. The physico-chemical, heavy metal and biological parameters of ground-water need to be studied to determine its quality. The present study mainly focuses on the physico-chemical characteristics in the ground water from the study area and the results (Table 1) were compared with BIS standards.

In the groundwater regime, all chemical and biological reactions directly depend on the $\mathrm{pH}$ of the system. The chemical state of groundwater is usually defined in terms of $\mathrm{pH}$, temperature and oxidation-reduction potential (Nelson, 2002). In the present study the $\mathrm{pH}$ of the ground water ranges from 7.12 to 8.20 with mean of 7.47 . None of the samples found to have exceeded the BIS limit (6.5-8.5) of $\mathrm{pH}$ for drinking water.

The conductivity of the ground water indicates its ionic strength and its degree of ionic mineralization, e.g. elevated concentrations of heavy metals (Naudet et al., 2004). The electrical conductivity (EC) of the ground water samples of the study area were ranges from 490 to $3711 \mu \mathrm{S} / \mathrm{cm}$, with mean of 
$1372 \mu \mathrm{S} / \mathrm{cm}$ (Table 1). Maximum value was recorded at Dabagardens $(3711 \mu \mathrm{S} / \mathrm{cm})$ while lowest value recorded at Tatichetlapalem (490 $\mu \mathrm{S} / \mathrm{cm})$. It is significant to mention that electrical conductivity of water at all the study sites was found to exceed the maximum permissible limits of $750 \mu \mathrm{S} / \mathrm{cm}$ for drinking water (BIS, 1991). High values of conductivity indicate high concentration of soluble salts present in ground water sources and reflect the contribution from seepage of domestic, industrial and municipal sewage (Hussain et al., 2002).

The concentration of total dissolved solids in water can be approximated in the field by measuring the specific conductance of a sample (Hem, 1985). Fresh water is usually considered to be water containing less than $1,000 \mathrm{mg} / \mathrm{L}$ total dissolved solids (Drever, 1988). The of total dissolved solids (TDS) of the ground water samples of the study area ranges from 330 to $2487 \mathrm{mg} / \mathrm{L}$, with mean of 920mg/L (Table 1). Maximum value recorded at Dabagardens $(3711 \mu \mathrm{S} / \mathrm{cm})$ while lowest value recorded at Tatichetlapalem (330 $\mu \mathrm{S} / \mathrm{cm})$. The reason of these changes could be the dissolution of salts and minerals, which are present in soil due to rise in water table. Kripanidhi (1984) reported similar trend in ground water of a typical hard rock terrain and pollution in village wells in Karnataka state.

Chlorides are leached from various rocks into soil and water by weathering (WHO, 1996). Chloride is the most abundant ion in seawater, with a concentration greater than $19,000 \mathrm{mg} / \mathrm{L}$ (Stumm and Morgan, 1996). The concentration of chloride in the ground water samples of the study area were ranges from 100 to $565 \mathrm{mg} / \mathrm{L}$, with a mean of $275 \mathrm{mg} / \mathrm{L}$. The concentration of chloride Maximum value was recorded at Dabagarden (565 $\mathrm{mg} / \mathrm{L}$ ) while lowest value recorded at Tadichetlapalem $(100 \mathrm{mg} / \mathrm{L})$ may be due to low water level and minimum in the rainy season due to dilution factor.

Fig.1 Showing sampling locations

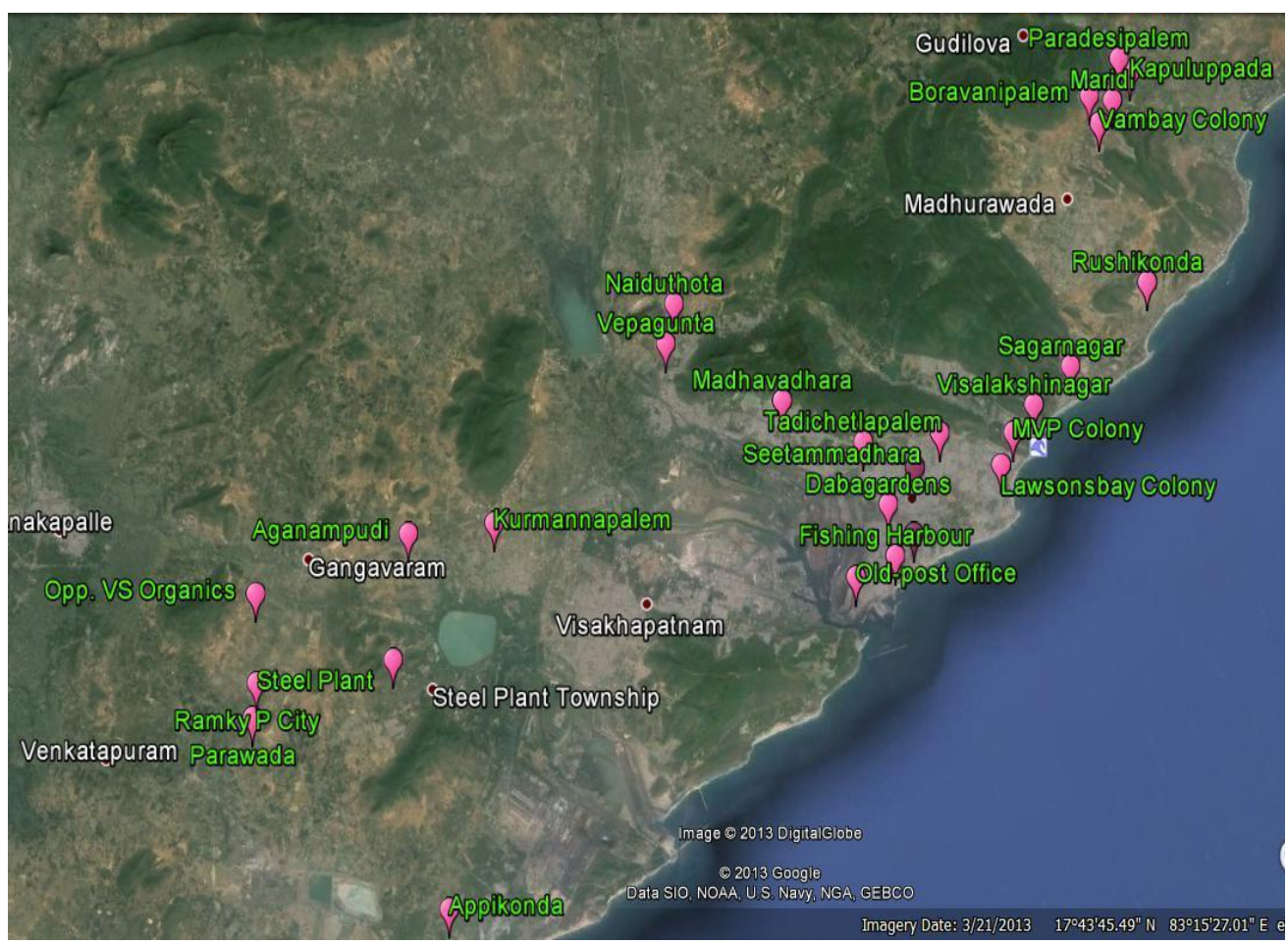


Table.1 Physico-chemical parameters of Visakhapatnam

\begin{tabular}{|c|c|c|c|c|c|c|c|c|c|}
\hline Location & $\bar{z}$ & U & $\tilde{\hat{\theta}}$ & 을 & $\stackrel{s}{\bar{E}}$ & 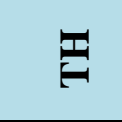 & 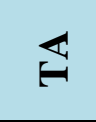 & 竞 & $\stackrel{8}{0}$ \\
\hline Paravada & 7.28 & 842 & 563 & 260 & 40 & 245 & 74 & 10 & 3.7 \\
\hline Opp V.S organics & 7.28 & 663 & 445 & 335 & 41 & 243 & 74 & 9 & 3.5 \\
\hline Appikonda & 7.56 & 1851 & 1240 & 365 & 140 & 461 & 73 & 5 & 2.5 \\
\hline Steel Plant & 7.42 & 1249 & 837 & 210 & 64 & 260 & 82 & 6 & 3.7 \\
\hline Aganampudi & 7.38 & 826 & 555 & 300 & 48 & 323 & 76 & 11 & 4.5 \\
\hline Kurmanapalem & 8.2 & 587 & 394 & 190 & 48 & 322 & 66 & 7 & 4.5 \\
\hline Tadichatlapalem & 7.12 & 490 & 330 & 100 & 26 & 158 & 105 & 12 & 5.3 \\
\hline Madavadhara & 7.36 & 1405 & 942 & 198 & 81 & 375 & 148 & 11 & 4.8 \\
\hline Gnana & 7.34 & 1693 & 1135 & 243 & 50 & 477 & 110 & 9 & 5.5 \\
\hline Allip & 7.36 & 858 & 576 & 229 & 41 & 262 & 134 & 10 & 5.4 \\
\hline Dwarakanaş & 7.69 & 2375 & 1591 & 420 & 125 & 248 & 148 & 6 & 5.9 \\
\hline Dabagardens & 7.76 & 3711 & 2487 & 565 & 229 & 1045 & 156 & 14 & 5.8 \\
\hline Seethammadhara & 7.39 & 1365 & 915 & 372 & 68 & 465 & 122 & 10 & 5.2 \\
\hline Fishi & 7.3 & 856 & 573 & 264 & 54 & 268 & 136 & 14 & 5.2 \\
\hline Old-p & 7.52 & 1635 & 1095 & 315 & 52 & 390 & 128 & 10 & 5.3 \\
\hline Maharanipeta & 7.42 & 1203 & 805 & 255 & 78 & 285 & 128 & 14 & 5.5 \\
\hline Lawsons Bay & 7.46 & 917 & 614 & 206 & 42 & 300 & 130 & 16 & 4 \\
\hline MVP & 7.62 & 1503 & 1006 & 204 & 98 & 440 & 104 & 14 & 4.8 \\
\hline agar & 7.32 & 755 & 507 & 212 & 42 & 256 & 116 & 13 & 4.1 \\
\hline Sagar & 7.37 & 1151 & 771 & 280 & 70 & 348 & 122 & 14 & 4.8 \\
\hline Rushikonda & 7.56 & 1703 & 1142 & 344 & 118 & 400 & 122 & 12 & 3.9 \\
\hline BoravaniPalem & 7.77 & 2009 & 1347 & 250 & 120 & 510 & 18 & 1.5 & 2.3 \\
\hline Kapuluppada & 7.6 & 1708 & 1146 & 340 & 126 & 510 & 16 & 1.4 & 4.6 \\
\hline Maridi & 7.34 & 1371 & 918 & 199 & 104 & 404 & 28 & 1.2 & 1.2 \\
\hline Vambay colony & 7.44 & 1582 & 1061 & 220 & 110 & 540 & 27 & 1.4 & 1.8 \\
\hline Min & 7.12 & 490 & 330 & 100 & 26 & 158 & 16 & 1.2 & 1.2 \\
\hline Max & 8.20 & 3711 & 2487 & 565 & 229 & 1045 & 156 & 16 & 5.9 \\
\hline Mean & 7.47 & 1372 & 920 & 275 & 81 & 381 & 98 & 9.3 & 4.3 \\
\hline IS Standards & 5- 8.5 & 750 & 500 & 250 & 200 & 300 & 200 & 45 & $>5$ \\
\hline
\end{tabular}

(Note: All the parameters are expressed in $\mathrm{mg} / \mathrm{L}$ except $\mathrm{pH} \& \mathrm{EC}$ )

(EC: Electrical Conductivity; TDS: Total Dissolved Oxygen; Chlo: Chloride; Sulp: Sulphate; TH: Total Hardness; TA: Total Alkalinity; Nit: Nitrate; DO: Dissolved Oxygen)

As per Indian Drinking Water Standard IS 10500: 1991 the desirable limit for chloride is $250 \mathrm{mg} / \mathrm{l}$ as $\mathrm{Cl}$, beyond this limit the taste become salty, corrosive and palatability is affected. Permissible limit in the absence of alternative source is $1000 \mathrm{mg} / \mathrm{l}$ (Sameer et al., 2011). Higher values of chlorides indicate pollution of water and give an undesirable taste. Higher values are hazardous to human consumption and create health problems (Kataria and Iqbal, 1995). People who are not accustomed to high Chloride in water are subjected to laxative effect as suggested by Raviprakash and Krishna Rao (1989).

Ground water impacts from anthropogenic sources of sulfate, however, are typically much smaller than from natural sources. 
Gypsum is an important source in many aquifers having high concentrations of sulfate (MPCA, 1999). The concentration of sulphate in the present study varies from 26 to 229 $\mathrm{mg} / \mathrm{L}$, with a mean of $81 \mathrm{mg} / \mathrm{L}$. Except one sampling location i.e. Dabagardens $(229 \mathrm{mg} / \mathrm{L})$ is exceeded and other of these samples below the BIS desirable limits (200 $\mathrm{mg} / \mathrm{L}$ ) and within the safe limit and ground water appears to be suitable for drinking purpose. The Minnesota Department of Health (MDH) recommends a limit of 400 $\mathrm{mg} / \mathrm{L}$ for water used in infants.

Hardness of water is due to the presence of divalent metallic cations, like calcium, magnesium, iron, and manganese ions (Sharma.2004). TH is normally expressed as the total concentration of $\mathrm{Ca}^{2+}$ and $\mathrm{Mg}^{2+}$ in mg $1^{-1}$, equivalent $\mathrm{CaCO}_{3}$ (Suman, 2006). The total hardness represented by $\mathrm{CaCo}_{3}$ concentrations in water ranges from 158 to $1045 \mathrm{mg} / \mathrm{L}$, with a mean of $381 \mathrm{mg} / \mathrm{L}$ (Table 1). Maximum concentrations were recorded at Dabagardens (1045 mg/L) while lowest concentration was recorded at Tadichetlapalem $(158 \mathrm{mg} / \mathrm{L})$. According to BIS, desirable limit of Total hardness and maximum permissible limits are $300 \mathrm{mg} / \mathrm{L}$ and $600 \mathrm{mg} / \mathrm{L}$ in ground water. The total hardness is relatively high in all samples due to the presence of calcium, magnesium, and chloride and sulphate ions to be found in areas with mainly igneous rock formations, while areas with mainly sedimentary rock tended to have greater water hardness (Rafi et al., 2011).

The constituents of Alkalinity in natural system mainly include Carbonate, Bicarbonate and Hydroxide. These constituents result from dissolution of mineral substances in the soil and atmosphere (Mittal and Verma, 1997). The alkalinity of ground water ranges from 16 to $156 \mathrm{mg} / \mathrm{L}$, with a mean of $99 \mathrm{mg} / \mathrm{L}$ (Table 1). Maximum concentrations were recorded at Sriharipuram
$(156 \mathrm{mg} / \mathrm{L})$ while lowest value at Kapuluppada Village $(16 \mathrm{mg} / \mathrm{L})$. The samples were detected to have alkalinity lower than the desirable limits of $200 \mathrm{mg} / \mathrm{L}$. A decrease in alkalinity value in the study area is ascribed to dilution due to rainfall (Khabede et al., 2003. Alkalinity itself is not harmful to human health: still water supplies with less than $100 \mathrm{mg} / \mathrm{L}$ are desirable for domestic use (Trivedi and Goel, 1984). Ramaswamy and Rangaraju (1991) reported higher alkalinity values in the ground water of Tirrupur, Tamilnadu that may be due to the contamination of these resources with domestic and industrial wastes. High values of alkalinity in the water samples indicate pollution of organic nature and give an unpleasant taste. In the absence of alternate source of water, alkalinity up to $600 \mathrm{mg} / \mathrm{L}$ is permissible (BIS, 1991).

Nitrate in aquatic system usually originates from nitrogenous fertilizers, domestic waste discharge and animal wastes (Peavy et al., 1986). The nitrogenous fertilizer used in intensive agriculture percolates down to ground water and it is probably one of the reasons for high concentration of nitrate.

The Nitrate concentration varies from 1.2 to $16 \mathrm{mg} / \mathrm{L}$, with a mean of $9.3 \mathrm{mg} / \mathrm{L}$. Maximum value was recorded at Lawsons Bay Colony $(16 \mathrm{mg} / \mathrm{L})$ and lowest value recorded at Maridi $(1.2 \mathrm{mg} / \mathrm{L})$. The desirable limit of nitrate in drinking water is $45 \mathrm{mg} / \mathrm{L}$ (BIS, 1991) / 50 ppm (WHO, 1984). The nitrate contents of ground water samples are well within the desirable limit in the present study.

Oxygen is the regulator of metabolic process of plant and animal communities and indicator of water condition (Gautham and Sharma, 2011). Dissolved oxygen is a highly fluctuating factor and this value varies depending upon water temperature and the partial pressure of oxygen in its gas phase 
(Renn, 1970). In the present study the value of DO ranges from 1.2 to $5.9 \mathrm{mg} / \mathrm{L}$ with mean of $4.3 \mathrm{mg} / \mathrm{L}$. Maximum value recorded at Dwarkanagar $(5.9 \mathrm{mg} / \mathrm{L})$ while minimum values were recorded at Maridi $(1.2 \mathrm{mg} / \mathrm{L})$. About most of the sampling locations not up to permissible according to drinking water quality standards (BIS, 2006) is $>5 \mathrm{mg} / \mathrm{L}$ (tolerance level). Due to physical chemical and biological activities in water, the dissolved oxygen was low in all the ground water. The DO values may also vary with the temperature and altitudinal change. Low DO in certain sites may be due to sewage, industrial and domestic solid waste seepage (Raja et al., 2002).

\section{References}

APHA (American Public Health Association). 2005. Standard method for examination of water and wastewater, NW, DC 20036.

BIS (Bureau of Indian Standards) 10500.1991. Indian standard drinking water- specification, First revision, pp 1-8.

BIS Tolerance limits for Inland surface water IS: 2296-1982 and BIS standard 2006.

Bureau of Indian Standards (BIS), 1991. Indian standard specification for drinking water, IS 10500, pp. 2-4.

Dennis Nelson., 2002. Natural Variations in the Composition of Groundwater; Presented at Groundwater Foundation Annual Meeting November.

Drever, J.I., 1988. The Geochemistry of Natural Waters, 2nd Edition: Prentice Hall, Inc., Englewood Cliffs, New Jersey, 402 p.

Gautham DK., M R Sharma. 2011. India Journal of Env. Protection 31(6) 464466.

Hem, J.D., 1985. Study and interpretation of the chemical characteristics of natural water: U.S. Geological Survey Water-
Supply Paper 2254, 263 p.

Hussain I.; L. Raschid; M. A. Hanjra; F. Marikar; W. van der Hoek. 2002. Wastewater use in agriculture: Review of impacts and methodological issues in valuing impacts. (With an extended list of bibliographical references).Working Paper 37. Colombo, Sri Lanka: International Water Management Institute.

Kataria, H.C. and Iqbal, S.A. 1995.Chloride Content in Borewells (Ground Water) of Bhopal City. Asian J. Chem Rev. 6: 35-38.

Khabade, S. K., Mule, M. B. and Sathe, S. S. 2002. Studies on physicochemical parameters of Iodhe water reservoir from Tasgaon Teshil (Maharastra): Indian. J. Environ and Ecoplan. 6(2): 301-304.

Krupanidhi, K. V. J. R. 1984. Mechanism of groundwater pollution in village wells. Journal of the Geological Society of India, 25(5), 301-302.

Minnesota Pollution Control Agency. 1999. Minnesota Water Quality - Water Years 1998-1999. The 2000 Report to the Congress of the United States. St. Paul, $\mathrm{MN}$.

Mittal, S.K. and Verma, N. 1997.Critical Analysis of Ground Water Quality Parameters. Indian J. Env. Prot. 17(6):426-429.

Mohemmad Rafi K., N. Md. Akram, M. Umamahesh and T. Ramachar. 2011. A Chemical Analysis of Groundwater and Study on its Pollution Impact in and Around Jammalamadugu Area of YSR District, Andhra Pradesh, India. International Journal of African Studies ISSN 1451-213X Issue 4, pp.41-49.

Naudet V., A. Revil, E. Rizzo, J.Y. Bottero and P. Begassat., 2004. Ground water redox conditions and conductivity in a contaminant plume from geoelectrical investigations; Hydrology and earth 
Systems Sciences, 8(1), 8-22.

Peavy, H.S., Rowl, D.R. and Techobunglons, G. 1986. Environmental Engineering. M.C. Graw Hall Book Company. New Delhi.

Ramaswami, V. and Rajaguru, P., 1991. Studies on ground water quality of Madras, Indian J. Environ. Hlth., 3 J. Environ. Hlth., 33, pp. 481-4867.

Raviprakash and Krishna, Rao, G. 1989. The Chemistry of Ground Water in Pravada area With Regard to their Suitability for Domestic and Irrigation Purpose. Indian J. Geochem. 4(1): $39-54$.

Renn, C.E.1970. Investigating water problems. Educational products division, La Moltechemical products company, Maryland.

Sameer. V. Yamakanamardi, Hampannavar. U.S, Purandara. B. K., 2011. Assessment of Chloride Concentration in Groundwater: A Case Study for Belgaum City; International Journal of Environmental Sciences Volume 2 No.1.

Sarma, V. V. J. and Swamy, A. N. 1981. Ground water quality in Visakhapatnam basin, India. Jour. Water, air and Soil
Pollution. 16, pp 317329.

Stumm, W., Morgan, J., 1996. Aquatic Chemistry. Chemical Equilibria and Rates in Natural Waters. Third Edition.

SumanMor, KhaiwalRavindra, R. P. Dahiya and A. Chandra., 2006. Leachate characterization and assessment of groundwater pollution near municipal solid waste landfill site; Environmental Monitoring and Assessment, 118: 435456.

Trivedi, R. K. and Goel, P. K. 1984. Chemical and biological methods for water pollution studies Karad Environmental Publication, pp. 1-251.

Trivedi. P, and P.K. Goel. 1986. Chemical and Biologiccal methods for water pollution studies. Environment Publications. pp.215.

WHO (World Health Organization). 1984. Guidelines for drinking water quality. vol. 2 Pp 80-95.

WHO. 1996. Health criteria and other supporting information; second ed. Guidelines for drinking water quality, Vol. 2. World Health Organization. Geneva. Switzerland.

\section{How to cite this article:}

Madhusudan Yaduvams, E., S.V. Ranga Rao, CH. Venkata Ramana and Byragi Reddy, T. 2017. Physico-Chemical Analysis of Ground Water in the Selected Area of Visakhapatnam, AP, India. Int.J.Curr.Microbiol.App.Sci. 6(12): 1252-1258. doi: https://doi.org/10.20546/ijcmas.2017.612.141 